\title{
BIOMECHANICAL ANALYSIS OF TENSION-COMPRESSION ASYMMETRY, ANISOTROPY AND HETEROGENEITY OF BONE RECONSTRUCTION IN RESPONSE TO PERIPROSTHETIC FRACTURE REPAIR
}

\author{
Zolochevsky O. O., Martynenko O. V.
}

Introduction. Bone repair after periprosthetic fracture is a critical issue in orthopedics.

Objectives. So there is a need for research to provide new medical solutions, especially in the context of population ageing in the Ukraine. The importance of biomechanics which is concerned with the application of principles, concepts and methods of mechanics of solid and fluid to the human body in motion and at rest is well recognized as a foundation for further experimental and theoretical research in the skeletal tissues.

Materials and methods. Different aspects of biomechanics require different concepts and methods of mechanics of solid and fluid to be used. Remodeling occurs significantly throughout lifetime of bone that is why it can be regarded as a primary determinant of the mechanical properties of bone and implant. Biomechanical analysis given in this review has been concerned with understanding on how mechanical signals and molecular mechanisms affect the healing of Vancouver periprosthetic femoral fracture of B1 and C-type with the use of internal fixation through a less invasive stabilization system (LISS)-plate, which is screwed into the artificial hip joint.

Results. Identification of such parameters as mechanical properties of bone, titanium alloys (hip prosthesis, coating, LISS-plate, screws) and implant/biomaterial interface with bone under mechanical and biochemical loading that are very essential for predicting arthroplasty outcomes were investigated experimentally considering elastoplastic deformation, creep, fatigue and ratcheting, as well as, damage development in materials under discussion. Among the basic deformation features were tension-compression asymmetry, anisotropy and heterogeneity of mechanical properties. We used the threedimensional finite element model derived from the reconstruction of treatment and magnetic resonance (tomographic) images.

Conclusions. As a result of this model analysis, it was found that treatment rate of periprosthetic femoral fractures after total hip arthroplasty with the use of LISS-plates and screws for internal fixation may be controlled by means of ABAQUS (or ANSYS) software package to reproduce the characteristic features of bone and implant in bone reconstruction in order to improve the fracture healing rate and shorten treatment duration.

KEY WORDS: periprosthetic fracture, LISS-plate, biomechanics, anisotropy, heterogeneity, tensioncompression asymmetry

\section{INFORMATION ABOUT AUTHORS}

Zolochevsky Olexander, Doctor of Technical Sciences, Associate Professor, Head of Laboratory, Research and Industrial Center «Polytech», 14, O. Yarosha st., Kharkiv, 61145, Phone: +38 (057) 710-40-86; e-mail: zolochevsky55@ukr.net, https://orcid.org/0000-0001-6632-4292

Martynenko Alexander, D. Sc., Professor, Department of Hygiene and Social Medicine, V. N. Karazin Kharkiv National University, 6, Svobody sq., Kharkiv, Ukraine, 61022, e-mail: Alexander.v.martynenko@karazin.ua https://orcid.org/0000-0002-0609-2220

\section{INTRODUCTION}

Bone repair after periprosthetic fracture is a critical issue in orthopedics [1]. Every year, for example, 350000 knee and hip prostheses are implanted solely in Germany [2]. Therefore, hip replacement is one of the ten most common surgeries. But due to a continuously increasing number of primary hip arthroplasties, the incidence of periprosthetic fractures is also increasing [3]. At present, up to $4-5 \%$ of all patients with implanted primary hip arthroplasties will suffer from a periprosthetic fracture at least once in their life, most commonly caused by a fall on the implanted hip $[1,4]$. Main reasons for these periprosthetic fractures are implant loosening, alteration of the femur's physiological properties and increasing patient's age $[2,4]$.

Post-operative femoral fractures are graded by the Vancouver classification (tab. 1). For surgical decision-making, the Vancouver classification has been proven most useful, and it is widely in use [1, 4]. 
Vancouver classification system of periprosthetic fractures [4]

\begin{tabular}{|l|l|l|}
\hline \multirow{2}{*}{ A } & Trochenttric region & AG: greater trochanter \\
\cline { 3 - 3 } & \multirow{2}{*}{ diaphysis } & AL: lesser trochanter \\
\hline \multirow{2}{*}{ B } & B1: stable arthroplasty \\
\cline { 3 - 3 } & B2: unstable arthroplasty \\
\cline { 3 - 3 } & Distal arthroplasty & B3: B2 with osseous defect \\
\hline C & ding & \\
\hline
\end{tabular}

The Vancouver B1 periprosthetic femoral fracture (tab. 1) assumes fracture around stem or just below, with stable arthroplasty [1, 2]. In the case of the Vancouver C fractures (tab. 1), fracture occurs below the prosthesis. Both types of the Vancouver periprosthetic femoral fractures (B1 and C) require surgery with plate and screw systems $[1,2]$. Hence, the novel medical approach is to fix the Vancouver $\mathrm{C}$ (or B1) periprosthetic fracture through a less invasive stabilization system (LISS)-plate, which is screwed into the artificial hip joint [14].

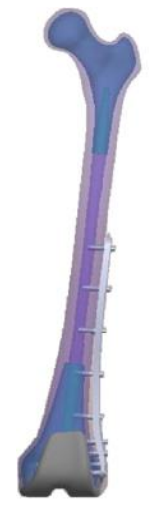

a

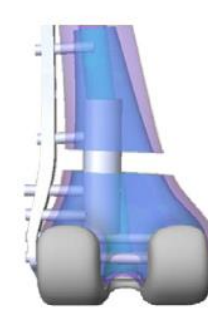

b
As an example, Figure 1 shows implants [5] which instrumented into the fractured femur, including LISS-plate and intramedullary nailing. The femur consists of cortical shell and cancellous core (Fig. 1a). Also, it is seen (Fig. 1a) how a 9-hole LISS plate was fixed to the distal femur with proximal and distal cortical screws. Periprosthetic fracture was simulated as a displaced 1-cm gap (Fig. 1b and c). Hence, transverse (Fig. 1b) and oblique (Fig. 1c) patterns of the periprosthetic fractures are considered.

Fig. 1. Internal fixator and fracture patterns: (a) LISS-plating, (b) transverse fracture, (c) oblique fracture [5]

\section{OBJECTIVE}

Practical recommendations related to the healing of Vancouver periprosthetic fractures of B1 and C-type with the use of LISS-plates and screws for internal fixation are mainly based on clinical experience. So there is a need for research to provide new medical solutions, especially in the context of population ageing in the Ukraine. Also, important themes include function and health related quality of life after surgery. Other aspects include clinical outcome analysis for different medical solutions in order to overcome many of the limitations of traditional surgery and to improve the ability to pain and carry out surgical interventions more accurately.

\section{MATERIALS AND METHODS}

The importance of biomechanics is well recognized as a foundation for further experimental and theoretical research in the skeletal tissues [6]. In general, biomechanics is an interdisciplinary field that involves the disciplines of biology, medicine and mechanics for health care purposes, including diagnosis, monitoring and therapy. The field of biomechanics is related to the study of structure 
and function of biological and medical systems using the approaches of mechanics of solid and fluid. In this way, it is possible to qualitatively and quantitatively understand biological phenomena that are fundamental in medicine. Thus, biomechanics is concerned with the application of principles, concepts and methods of mechanics of solid and fluid to the human body in motion and at rest.

Different aspects of biomechanics require different concepts and methods of mechanics of solid and fluid to be used. At the same time, it is necessary to take into account that three processes account for the amount of bone we have, and for where it is found in our skeletons, such as, growth, modeling and remodeling [6]. Remodeling is the only one of these processes that occurs significantly throughout lifetime of bone. Consequently, remodeling is a primary determinant of the mechanical properties of bone and implant.

Development of practical recommendations in response to the healing of Vancouver periprosthetic fractures of $\mathrm{B} 1$ and C-type requires the knowledge of mechanical properties of bone, titanium alloys (hip prosthesis, coating, LISS-plate, screws) and implant/biomaterial interface with bone under mechanical and biochemical loading. Such mechanical properties can be investigated experimentally considering elastoplastic deformation, creep, fatigue and ratcheting, as well as, damage development in materials under discussion [7]. Among the basic deformation features of these materials are tensioncompression asymmetry, anisotropy and heterogeneity of mechanical properties.

\section{RESULTS AND DISCUSSION}

Tension-compression asymmetry. Bone shows different mechanical properties in tension and compression identically to any other material $[8,9]$. In this regard, bone must demonstrate different stress-strain diagrams $[10,11]$, different creep curves $[12,13]$, different fatigue behavior $[14,15]$ and different damage development $[16,17]$ under tensile and compressive loading types for one and the same anatomic situation.

Stress-strain diagrams of human cranial bone under uniaxial tension were obtained for over 120 specimens at strain rates ranging from 0.01 to $150 \mathrm{~s}^{-1}$ [18]. It is seen (Fig. 2) the good correlation between the experimental and simulation results [19].

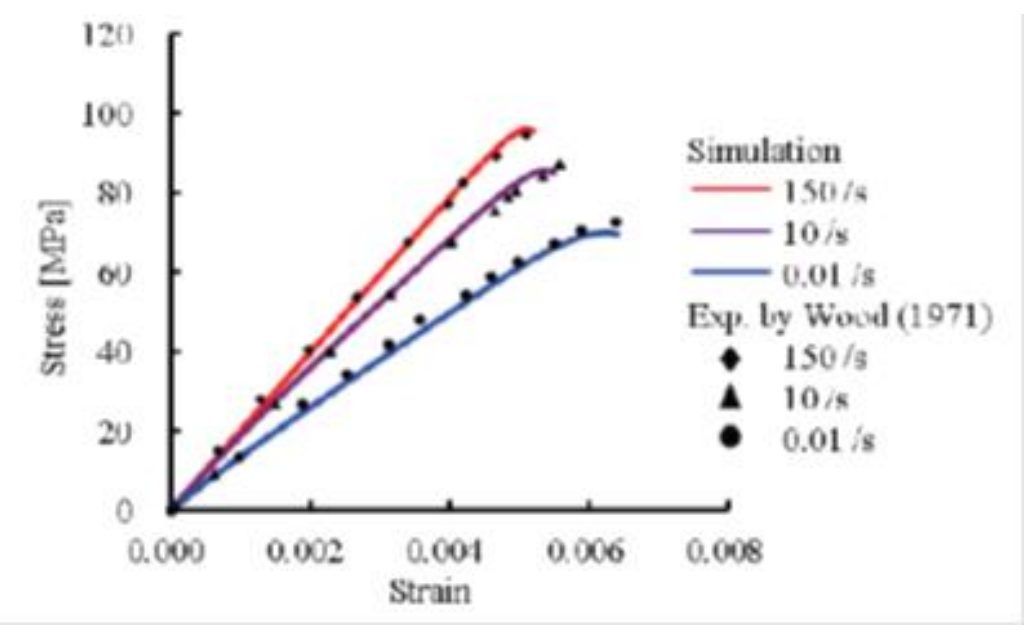

Fig. 2. Comparison of experimental data for cortical bone in tension [18] with simulation results [19]

Stress-strain diagrams of embalmed human femur under uniaxial compression were obtained for six different strain rates of $1500,300,1,0.1,0.01$ and $0.001 \mathrm{~s}^{-1}$ [20].
Comparison between the experimental and simulation results has been given in Fig. 3 [19]. 


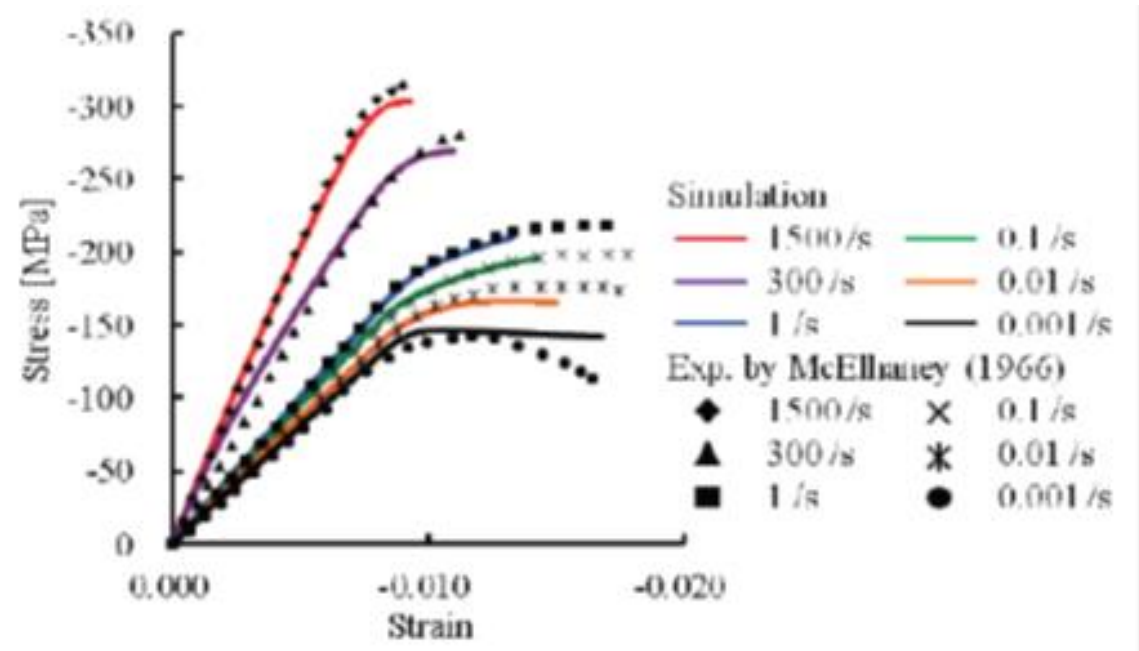

Fig. 3. Comparison of experimental data for cortical bone in compression [20] with simulation results [19]

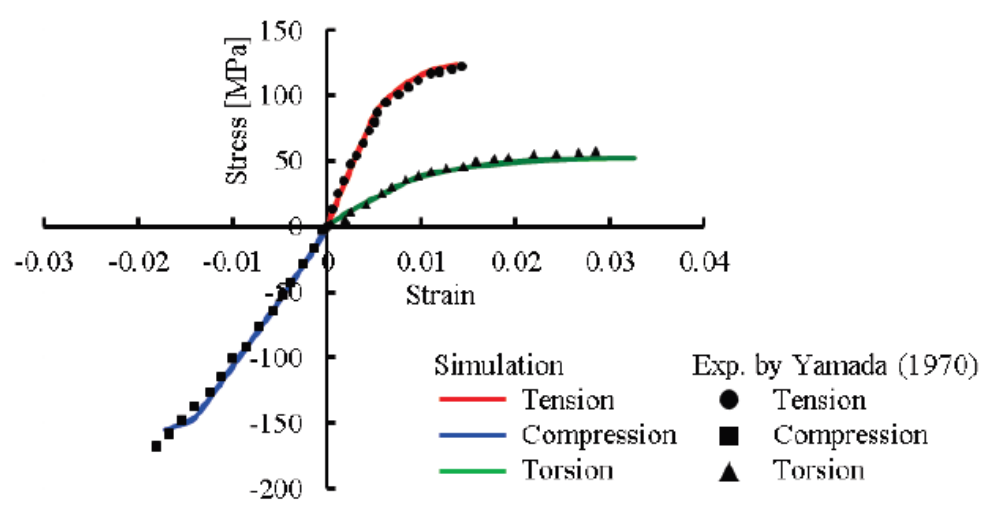

Fig. 4. Comparison of experimental data for cortical bone in tension, compression and torsion [21] with simulation results [19]

Experimental data discussed above demonstrate tension/compression asymmetry of bone, but, unfortunately, they were obtained by different authors and at different laboratories and conditions. The influence of the kind of loading on the mechanical behavior of femur was studied experimentally by Yamada [21]. For this purpose, such experiments, as uniaxial tension, uniaxial compression and pure torsion were conducted. Figure 4 shows the stress-strain diagrams of femur influenced by type of loading, as well as, the correlation between the experimental and simulation results [19].

Experimental data related to the tensioncompression asymmetry of bone in response to creep, fatigue, ratcheting and damage development have been analyzed earlier in [7]. Tension-compression asymmetry of titanium alloys has been discussed in detail in $[8,9]$.

Experimental data given in Figs. 2-4 were obtained under monotonic loading. Stressstrain diagrams of bone under cyclic loading are presented in Fig. 5. It is clear that the unloading curves are deviated from the socalled linear unloading response. Also, it is seen (Fig. 5) the difference in mechanical behavior under unloading and reloading. Plastic (irreversible) strain data under cyclic loading include ratcheting part that reflects the influence of damage on the mechanical behavior of bones under fatigue conditions. 


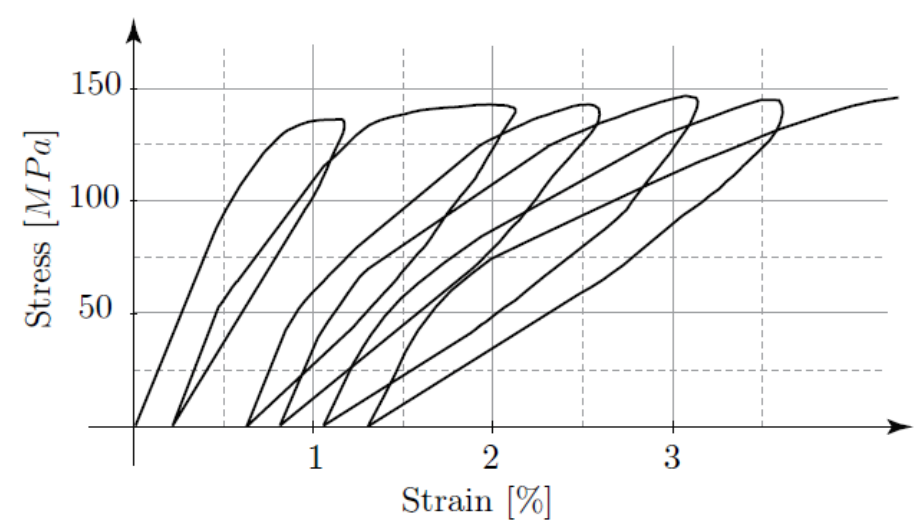

Fig. 5. Stress-strain diagram of cortical bone under cyclic tensile loading [22]

The comparison of experimental data under cyclic tension and cyclic compression (Fig. 6) shows the effect of the kind of stress

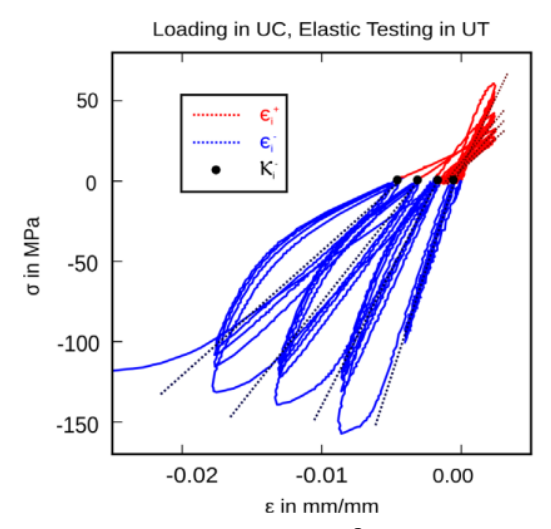

state on the processes of deformation of bone under cyclic loading.

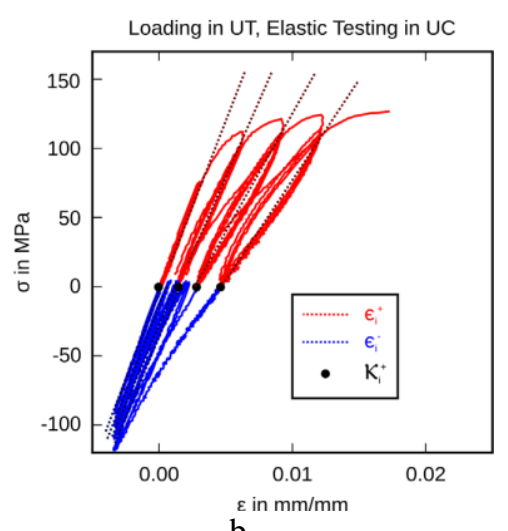

b

Fig. 6. Stress-strain curves for osteonal bone under cyclic compression (a) and cyclic tension (b) [23]

Initial anisotropy. At the cellular scale, bone is composed of bone matrix, infiltrated with minerals and with the osteocyte network, and soft tissues and cells. The mechanical properties of bones depend strongly on the variable structure of the material inside bones. Basically, bone is an anisotropic material in nature. The initial anisotropy of bone is related to the dependence of mechanical properties on the orientation at a point in bone under consideration. Fortunately, such anisotropy occurs in bones in a form of the orthotropy or transverse isotropy because of symmetries in the material microstructure [6]. Orthotropic materials have three planes of symmetry, and the mechanical properties of orthotropic materials are different in three perpendicular directions (the longitudinal, radial, and circumferential direction of bone). The transverse isotropy is a particular case of the orthotropy when bone behaves similarly in every direction about a single axis of symmetry.

Experiments on bone samples collected from animals have been used commonly instead of human experiments to study the mechanical properties. For example, the comparison of the longitudinal (in alignment with the physiological axis) and transverse stress-strain characteristics of bovine femurs under tensile and compressive loading types is presented in Table 2 [24]. Such comparison is given for modulus of elasticity $E$, limits of linear elasticity for stress $\sigma_{\mathrm{y}}$ and $\operatorname{strain} \varepsilon_{\mathrm{y}}$, ultimate stress $\sigma_{\mathrm{u}}$ and ultimate strain $\varepsilon_{\mathrm{u}}$. Tests clearly demonstrate that bone is more resistant in the longitudinal direction than in the transverse direction. Mechanical properties of bovine bone are similar to that of human bone [6]. At the same time, modulus of elasticity in bovine is much higher than in mouse [25]. 
Mechanical properties of cortical bone in tension and compression [24]

\begin{tabular}{|c|c|c|c|c|c|c|}
\hline Orientation & $\begin{array}{c}\text { Loading } \\
\text { type }\end{array}$ & $\begin{array}{c}\mathbf{E} \\
(\mathbf{G P a})\end{array}$ & $\begin{array}{c}\sigma_{\mathrm{y}} \\
(\mathbf{M P a})\end{array}$ & $\begin{array}{c}\varepsilon_{\mathrm{y}} \\
(\%)\end{array}$ & $\begin{array}{c}\sigma_{\mathrm{u}} \\
(\mathrm{MPa})\end{array}$ & $\begin{array}{c}\varepsilon_{\mathrm{u}} \\
(\%)\end{array}$ \\
\hline \multirow{5}{*}{ Longitudinal } & \multirow[b]{2}{*}{ Compression } & 19.09 & 184.62 & 1.20 & 214.39 & 2.37 \\
\hline & & \pm 2.84 & \pm 22.51 & \pm 0.09 & \pm 27.57 & \pm 0.38 \\
\hline & \multirow{3}{*}{ Tension } & & & & & \\
\hline & & 20.22 & 75.85 & 0.61 & 97.41 & 1.85 \\
\hline & & \pm 3.12 & \pm 13.98 & \pm 0.11 & \pm 19.88 & \pm 0.39 \\
\hline \multirow{5}{*}{ Transverse } & \multirow{2}{*}{ Compression } & 11.62 & 112.78 & 1.06 & 131.16 & 2.40 \\
\hline & & \pm 2.4 & \pm 19.61 & \pm 0.21 & \pm 22.02 & \pm 0.73 \\
\hline & \multirow{3}{*}{ Tension } & & & & & \\
\hline & & 12.43 & 32.92 & 0.27 & 40.18 & 0.54 \\
\hline & & \pm 2.37 & \pm 7.85 & \pm 0.09 & \pm 9 & \pm 0.18 \\
\hline
\end{tabular}

The difference between the longitudinal and transverse creep curves of cortical bone has been shown in [26]. The anisotropic mechanical behavior of cortical bone under cyclic loading has been studied in [27-30]. Bone samples were prepared in the longitudinal, circumferential and radial directions of femur. Initial anisotropy of the fatigue and ratcheting of cancellous bone has been studied experimentally in [31].

Also, it is necessary to take into account the anisotropic mechanical properties of the titanium alloys. For example, the experimental data obtained on the samples taken in different directions of a Ti-6Al-4V plate demonstrate the initial anisotropy of creep and creep damage [32, 33]. So, the rupture time of the longitudinal samples is less by a factor of 30 than one obtained on the transverse samples for one and the same value of the tensile stress in the creep experiments. Anisotropy of the fatigue and ratcheting of Ti-6Al-4V has been studied experimentally in [34].

Heterogeneity. Bone is highly heterogeneous in its nature. For example, the stress-strain diagrams of cortical bone for specimens cut from four anatomical quadrants of bovine femurs are essentially different [24]. Additionally, cancellous bone is substantially weaker and more compliant than cortical bone [6].

In this regard, the material properties of bone are frequently discussed in terms of its apparent density $\rho$. The typical range of apparent density in cancellous bone is 1.0$1.4 \mathrm{~g} / \mathrm{cm}^{3}$, compared to about $1.8-2.0 \mathrm{~g} / \mathrm{cm}^{3}$, for compact bone [6]. Values of $\rho$ lower than $0.25 \mathrm{~g} / \mathrm{cm}^{3}$ correspond to the fracture of osteoporotic bone [35].
Modulus of elasticity has been related to density by the relationship [6].

$$
E=R \rho^{p}
$$

where $R$ and $\rho$ are material parameters, and exponent $\rho=2$ for cortical bone and $\rho=3$ for cancellous bone. Also, it is possible to use the approximations given in [36] considering the bone density instead of temperature. Let, the modulus of elasticity of bone with densities $\rho_{1}$ and $\rho_{2}\left(\rho_{2}>\rho_{1}\right)$ can be defined by the expressions $E=R_{1} \rho^{p_{1}}$ and $E=R_{2} \rho^{p_{2}}$, respectively. Then, the modulus of bone with density $\rho \in\left[\rho_{1}, \rho_{2}\right]$ can be determined with use of Eq. (1) and an interpolation procedure, such as

$$
R=R_{1}^{1-r} R_{2}^{r}, p=(1-r) p_{1}+r p_{2},
$$

where $r=\eta \frac{\rho_{2}}{\rho}$ and $\eta=\frac{\rho-\rho_{1}}{\rho_{2}-\rho_{1}}$. Thus, Eq. (1) corresponds to the modulus of elasticity of bone with material parameters defined for density $\rho \in\left[\rho_{1}, \rho_{2}\right]$ by Eq. (2).

Biomechanics. Considering bone and titanium alloy as anisotropic materials with different behavior in tension and compression, the connection between the kinematic tensor $e_{k l}$ and stress tensor $\sigma_{k l}$ in the bone reconstruction can be written as follows [37, 38]:

$$
e_{i j}=e_{0}\left(\frac{a_{i j k l} \sigma_{k l}}{\sigma_{2}}+b_{i j}\right) \text {. }
$$

Here $e_{0} \sigma_{e}=\sigma_{i j} e_{i j} ; \sigma_{e}=\sigma_{1}+\sigma_{2} ; \sigma_{1}=b_{i j} \sigma_{i j}$; $\sigma_{2}^{2}=a_{i j k l} \sigma_{i j} \sigma_{k l} ; b_{i j}$ and $a_{i j k l}$ are the second order and fourth order material tensors; $\sigma_{1}$ and $\sigma_{2}^{2}$ are the linear and quadratic joint invariants of the stress and the material 
tensors; $\sigma_{e}$ is the equivalent stress; $e_{0}$ is the scalar function which depends on $\sigma_{e}$, as well as, some structural parameters and specifies for each physical state of the material (elasticity, plasticity, creep).

In the case of the nonlinear elasticity, the kinematic tensor $e_{k l} \equiv \varepsilon_{k l}^{e}$ is the tensor of the elastic strain, and it is possible to assume that

$$
e_{0}=\frac{v\left(\sigma_{e}\right)}{(1-\omega)^{m}}
$$

where $\omega$ is a continuum damage variable by Kachanov-Rabotnov introduced to describe the damage growth in the bone reconstruction [7], different examples on how to specify the function $v\left(\sigma_{e}\right)$ are given in [8,9].

For plastic deformation of anisotropic materials with the strain hardening measure $q$ and condition of plasticity

$$
v\left(\sigma_{e}\right)=q,
$$

the kinematic tensor $e_{k l} \equiv \dot{\varepsilon}_{k l}^{p}$ in Eq. (3) is the tensor of the rates of the plastic strain, the dot above the symbol denotes a derivative with respect to the loading parameter, and the scalar multiplier in Eq. (3) can be defined as

$$
e_{0}=\chi v^{\prime}\left(\sigma_{e}\right) \dot{\sigma}_{e} .
$$

Here the prime denotes a derivative with respect to $\sigma_{e}$, and $\chi=0$ when $v\left(\sigma_{e}\right)<q$ and elastic deformation occurs, and either in the case of unloading or neutral loading when Eq. (5) takes place together with condition $\dot{\sigma}_{e} \leq 0$. Also, $\chi=1$ in the case of loading when Eq. (5) is valid simultaneously with inequality $\dot{\sigma}_{e}>0$.

Considering creep hardening with the measure $q$ and creep damage of anisotropic materials, it is possible to assume that the kinematic tensor $e_{k l} \equiv \dot{\varepsilon}_{k l}^{c}$ in Eq. (3) is the tensor of the rates of the creep strain, the dot above the symbol denotes a derivative with respect to the time $t$, and the scalar multiplier in Eq. (3) can be defined as

$$
e_{0}=\frac{v\left(\sigma_{e}\right) \xi(q)}{(1-\omega)^{m}} .
$$

Different examples on how to specify the functions $v\left(\sigma_{e}\right), \xi(q)$ and damage evolution equation for $\omega$ are given in $[8,9]$.

Now, a number of comments need to be made in reference to Eq. (3). First, the relationship between tensors under discussion was used in [39-42], however, without referencing sources $[37,38]$. Second, further development of the constitutive framework was given in $[8,9,43,44]$ based on the additional introduction of the sixth order material tensor and the cubic joint invariant of the stress and material tensors. Third, the determination of the material parameters in Eq. (3) is obtained from a series of basic experiments outlined in $[8,9,37,38]$. Finally, material parameters under consideration are functions of bone density which can be specified by analogy with Eqs. (1) and (2).

For orthotropic materials with coincidence of the coordinate axes with the principal directions of anisotropy Eq. (3) takes the following form [37, 38]:

$$
\begin{aligned}
& e_{11}=e_{0}\left(\frac{a_{1111} \sigma_{11}+a_{1122} \sigma_{22}+a_{1133} \sigma_{33}}{\sigma_{2}}+b_{11}\right), \\
& e_{12}=2 e_{0} \frac{a_{1212} \sigma_{12}}{\sigma_{2}} \quad(1,2,3) .
\end{aligned}
$$

Here the symbol $(1,2,3)$ means that the rest of the relations can be obtained from Eq. (8) by circular transposition of lower indexes 1,2 and $3 ; \sigma_{1}=b_{11} \sigma_{11}+b_{22} \sigma_{22}+b_{33} \sigma_{33}$; $\sigma_{2}^{2}=a_{1111} \sigma_{11}^{2}+a_{2222} \sigma_{22}^{2}+a_{3333} \sigma_{33}^{2}+2 a_{1122} \sigma_{11} \sigma_{22}+$ $+2 a_{1133} \sigma_{11} \sigma_{33}+2 a_{2233} \sigma_{22} \sigma_{33}+4 a_{1212} \sigma_{12}^{2}+4 a_{1313} \sigma_{13}^{2}+4 a_{2323} \sigma_{23}^{2}$ In a particular case of the transverse isotropy of bone or titanium alloy with a single axis of symmetry 1 the following equalities in Eq.

(8) hold [45] $b_{22}=b_{33} ; a_{2222}=a_{3333}$;

$$
a_{1122}=a_{1133} ; a_{1212}=a_{1313} ; a_{2222}=2 a_{2323}+a_{2233} \text {. }
$$

Further simplification of Eq. (8) for orthotropic materials with coincidence of the coordinate axes with the principal directions of anisotropy is related to the following requirements $[46,47]$

$$
\begin{aligned}
& a_{1111}=a_{11}^{2}, 2 a_{1122}=-a_{11} a_{22}, \\
& 4 a_{1212}=3 a_{11} a_{22}+a_{12}^{2}(1,2,3)
\end{aligned}
$$

based on the six material parameters $a_{11}, a_{22}$, $a_{33}, a_{12}, a_{23}$ and $a_{13}$. Making use of Eqs. (8) and (9) one obtains the following tensor relationship [47]

$$
\begin{aligned}
& e_{11}=e_{0}\left[\frac{a_{11}^{2} \sigma_{11}-\frac{1}{2}\left(a_{11} a_{22} \sigma_{22}+a_{11} a_{33} \sigma_{33}\right)}{\sigma_{2}}+b_{11}\right], \\
& e_{12}=\frac{1}{2} e_{0} \frac{\left(3 a_{11} a_{22}+a_{12}^{2}\right) \sigma_{12}}{\sigma_{2}}(1,2,3),
\end{aligned}
$$


where $\sigma_{2}^{2}=a_{11}^{2} \sigma_{11}^{2}+a_{22}^{2} \sigma_{22}^{2}+a_{33}^{2} \sigma_{33}^{2}-a_{11} a_{22} \sigma_{11} \sigma_{22}$

$-a_{11} a_{33} \sigma_{11} \sigma_{33}-a_{22} a_{33} \sigma_{22} \sigma_{33}+$

$+\left(3 a_{11} a_{22}+a_{12}^{2}\right) \sigma_{12}^{2}+\left(3 a_{11} a_{33}+a_{13}^{2}\right) \sigma_{13}^{2}+\left(3 a_{22} a_{33}+a_{23}^{2}\right) \sigma_{23}^{2}$

Definition of principal directions of anisotropy in biomechanical analysis must reflect the real anatomical situation in the femur. For example, principal directions of orthotropy for the cortical bone in the femur neck, trochanter minor or major are different from the orthotropy orientations in femur diaphysis [48]. Furthermore, principal directions of anisotropy in the cortical bone and cancellous bone are not the same. For orthotropic materials where the coordinate axes do not coincide with the principal axes of anisotropy, the tensor relationship can be written in the same way as Eq. (3), such as

$$
e_{i j}=e_{0}\left(\frac{a_{i j k l}^{\prime} \sigma_{k l}}{\sigma_{2}}+b_{i j}^{\prime}\right) \text {, }
$$

with new material tensors transformed in accordance with the customary transformation rules for fourth- and second order tensors

$$
a_{i j k l}^{\prime}=\alpha_{m i} \alpha_{n j} \alpha_{p k} \alpha_{q l} a_{m n p q} ; b_{i j}^{\prime}=\alpha_{m i} \alpha_{n j} b_{m n},
$$

where the components $\alpha_{i j}$ are the direction cosines of the angles between the principal axes of the anisotropy and the new coordinate axes. The symmetrical material tensors $a_{i j k l}^{\prime}$ and $\quad b_{i j}^{\prime}$ contain 21 independent components and six ones, respectively.
The process of bone remodeling after reconstruction can be described using the Wolff's law and taking into account changing its shape and density [49]. In general, the variation in bone density at the remodeling site can be calculated using two approaches. The first one is related to the cell population dynamics that is governed by the interactions between osteoblasts and osteoclasts through the expression of several autocrine and paracrine factors. This approach has been described in detail, for example, in [7, 50]. The second one is a phenomenological approach that is driven, for example, by the strain energy density $S$ as a mechanical stimulus, and the variation in bone density with time at the remodeling site can be expressed as follows [51]

$$
\frac{\mathrm{d} \rho}{\mathrm{d} t}=k\left(\frac{S}{S_{\text {ref }}}-1\right)
$$

where $S_{\text {ref }}$ is a reference value of the strain energy density, and $k$ is the bone resorption rate (or bone formation rate) that can be defined in accordance with Fig. 9. Hence, four phases of bone remodeling should be considered [51]: (1) Resorption due to disuse, if $S<S_{R}$; (2) Lazy zone, where bone mass is kept constant (no resorption and no formation), if $S_{R} \leq S \leq S_{F}$;(3) Formation due to strain stimulus dominated, if $S_{F}<S<S_{D}$; and (4) Resorption due to damage healing, if $S>S_{D}$.

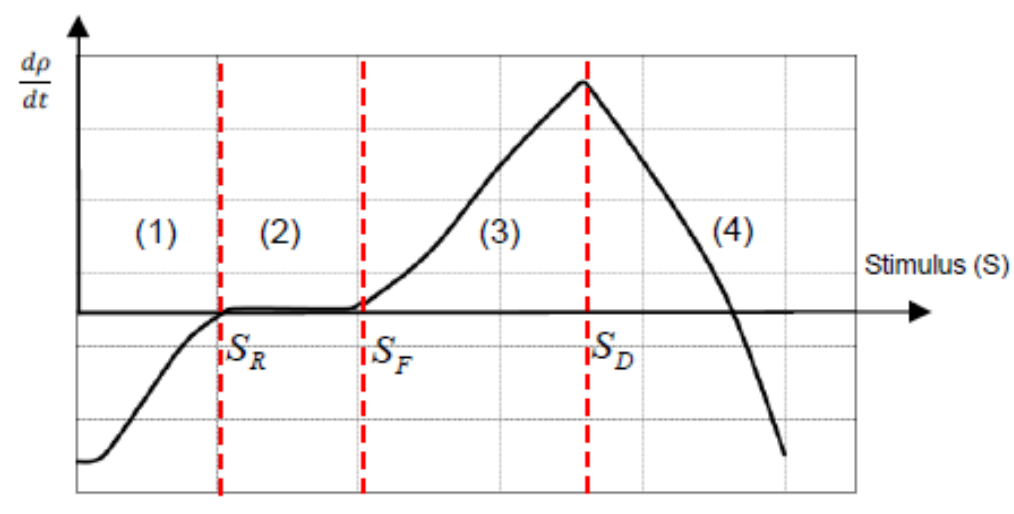

Fig. 7. Bone adaptation model with four states of remodeling [51]

Modeling osteogenesis within a porous titanium implant is necessary for understanding how the implant/biomaterial interface with bone, translation of mechanical to biological signals and treatment of periprosthetic femur fractures after total hip arthroplasty with the use of LISS-plates and screws for internal fixation may be controlled in order to improve the fracture healing rate and shorten treatment duration. Review of such models was given in [52]. 
Histological observations show proliferation of mesenchymal stem cells into a porous titanium implant [52]. In this regard, diffusion model was used to describe osteogenesis within a porous titanium scaffold [52-54]. As known [55-57], the diffusion of matter into a body can lead to such phenomena as swelling and diffusion induced stresses. Thus, the possibility of these phenomena should therefore be taken into consideration in biomechanical analysis of bone reconstruction.

Total strains are assumed to be composed of an elastic part, plastic part, swelling induced part and a part due to creep. The tensor of the swelling induced strain in the scaffold can be written as follows

$$
\varepsilon_{k l}^{s}=A\left(C-C_{0}\right) \delta_{k l},
$$

where $A$ is the biochemical expansion coefficient, $C$ is the concentration of mesenchymal stem cells defined by Fick's law [55-57], $C_{0}$ is the concentration of mesenchymal stem cells at the reference state, and $\delta_{k l}$ is the Kronecker delta. The other components of the strain tensor in bone and implant are defined by Eq. (11).

Software. The finite element method is a powerful technique for stress analysis in the case of the treatment of periprosthetic femur fractures after total hip arthroplasty with the use of LISS-plates and screws for internal fixation $[2,3]$. The impact of intraprosthetic drilling on the stress distribution, as well as, on the fracture risk of the femur has been investigated using commercial software package ANSYS. The effect of the prosthesis material stiffness on the mechanical behavior of femoral bone has been studied. For this purpose, titanium alloy and cobalt-iron alloy have been considered.

The finite element method was used in [5] to evaluate the differences between retrograde intramedullary nail and locking plate fixation with/without a strut allograft. The finite element study using ANSYS software gives the possibility to analyze the optimum design of the LISS femoral plate and determines how the movement at the fracture site is influenced by the preconditions of bone healing. The contact behavior of the screw/ femur and screw/plate interfaces was set as fully bonded to ensure the load transmission from the bone to the implant.
The effects of variations in plate positioning on predicted fixation failure risk was studied using commercial software package ABAQUS [58]. In this way, different clinical scenarios were investigated. It is shown the dominant role of calcar screws over others in reducing failure risk. It was found that the locations, rather than the average lengths of the screws, seem to be more critical for fixation stability.

Note that all these studies $[2,3,5,58]$ are based on the linear elastic behavior of bone, implant, plate and screws. The materials were assumed to be isotropic. Bone remodeling and implant remodeling processes were not considered.

The influence of microstructure on reconstructed bone remodeling was studied in $[59,60]$. One-, two- and three-dimensional simulations are presented using the COMSOL software. Anisotropy, tension-compression asymmetry, plasticity and creep were not included in the modeling analysis.

Cortical long bone at the metaphyses demonstrates the geometry of the thin shell ranging in thickness from 0.1 to $0.2 \mathrm{~mm}$ [61]. In this regard, the nonlinear theory of thin shells developed in $[62,63]$ can be used for analysis of bone density, stress and damage distributions over time in metaphyseal bone. The in-house developed software takes into account the tension-compression asymmetry, anisotropy, heterogeneity, plasticity, creep and damage development. In this way, the theory of moderately thick shells $[64,65]$ can be also considered. It is interesting to note that the theory of thin shells was also used in the bone remodeling analysis of diaphyseal surfaces under torsion [66]. Additionally, it is possible to check the assumption given by Eq. (9) in the constitutive framework under discussion comparing the experimental data of microcracking around a circular hole in a flat plate of bone under tensile loading [67] with predictions based on the theory of damage development in a thin plate of arbitrary shape [68].

The geometric model, such as a thickwalled hollow cylinder, has been applied for the diaphyseal region of a long bone [69-71]. In this case, three-dimensional nonlinear theory $[72,73]$ can be used with the in-house developed software that takes into account the anisotropy, tension-compression asymmetry, heterogeneity, plasticity, creep and 
damage growth. The experimental data [74] of stress relaxation in a thick-walled solid cylinder of bone can be also compared with the numerical predictions.

Constitutive models implemented into ANSYS [55, 57] and ABAQUS [75] give the possibility to reproduce the characteristic features of bone and implant, and need to be applied for analysis of bone density, stress and damage distributions over time in bone reconstruction. The practical recommenddations obtained in the simulations need to be compared with the experimental data [76] available for bone reconstructed with the use of LISS-plates and screws for internal fixation.

\section{CONCLUSIONS}

The three-dimensional finite element model derived from the reconstruction of treatment or magnetic resonance (tomographic) images may help to effectively simulate the influences of treatment on the mechanical behavior of femur. MATERIALISE MIMICS software will be used as the interface between computed tomography images of the reconstructed bone and ABAQUS (or ANSYS) software package.

The outcome of the finite element analysis will be how the implant/biomaterial interface with bone, translation of mechanical to biological signals and treatment of periprosthetic femoral fractures after total hip arthroplasty with the use of LISS-plates and screws for internal fixation may be controlled in order to improve the fracture healing rate and shorten treatment duration.

\section{REFERENCES}

1. Herzen, G. I., Shtonda, D. V. (2013). Periprosthetic femoral fractures after endoprosthetic replacement of the hip joint: The causes, classification and treatment. Proceedings of the Shupyk National Medical Academy of Postgraduate Education of Ukraine, 22(1), 308-314.

2. Bauer, M., Brand, S., Schrader, J., Krettek, C. Maier, H. J.; Hassel, T. (2017). Local stress investigation of periprosthetic fractures by total hip replacement: A finite element analysis. BMTMedPhys 2017. Poster session 11: Modelling and simulation I. Dresden, 10.09. - 13.09.2017, S. 152

3. Brand, S., Bauer, M., Petri, M., Schrader, J., Maier, H. J., Krettek, C., Hassel, T. (2016). Impact of intraprosthetic drilling on the strength of the femoral stem in periprosthetic fractures: A finite element investigation. Proceedings of the Institution of Mechanical Engineers, Part H: Journal of Engineering in Medicine, 230(7), 675-681.

4. Brand, S., Ettinger, M., Omar, M., Hawi, N., Krettek, C., Petri, M. (2015). Concepts and potential future developments for treatment of periprosthetic proximal femoral fractures. The Open Orthopaedics Journal, 9, 405-411.

5. Chen, S. H., Chiang, M. C., Hung, C. H., Lin, S. C., Chang, H. W. (2014). Finite element comparison of retrograde intramedullary nailing and locking plate fixation with/without an intramedullary allograft for distal femur fracture following total knee arthroplasty. The Knee, 21(1), 224-231.

6. Martin, R. B., Burr, D. B., Sharkey, N. A., Fyhrie, D. P. (2015). Skeletal Tissue Mechanics. New York: Springer, Second Edition, $501 \mathrm{p}$.

7. Martynenko, O. V., Zolochevsky, O. O., Allena, R. (2017). Long term evolution of bone reconstruction with bone graft substitutes. The Journal of V. N. Karazin Kharkiv National University. Series «Medicine», (33), 107-118.

8. Altenbach, H., Altenbach, J., Zolochevsky, A. (1995). Erweiterte Deformationsmodelle und Versagenskriterien der Werkstoffmechanik. Stuttgart: Deutsher Verlag für Grundstoffindustrie, 172S. (in German)

9. Zolochevsky, A. A., Sklepus, A. N., Sklepus, S. N. (2011). Nonlinear Solid Mechanics. Kharkiv: Garant, 719 p. (in Russian)

10. Zolochevskii, A. A. (1988). Modification of the theory of plasticity of materials differently resistant to tension and compression for simple loading processes. International Applied Mechanics, 24(12), 12121217.

11. Mahnken, R., Schlimmer, M. (2005). Simulation of strength difference in elasto-plasticity for adhesive materials. International Journal for Numerical Methods in Engineering, 63(10), 1461-1477.

12. Zolochevskij, A. A. (1988). Kriechen von Konstruktionselementen aus Materialien mit von der Belastung abhängigen Charakteristiken. Technische Mechanik, 9 (3), 177-184. (in German)

13. Mahnken, R. (2003). Creep simulation of asymmetric effects by use of stress mode dependent weighting functions. International Journal of Solids and Structures, 40(22), 6189-6209.

14. Altenbach, H., Zolochevsky, A. (1996). A generalized fatigue limit criterion and a unified theory of 
low-cycle fatigue damage. Fatigue \& Fracture of Engineering Materials \& Structures, 19(10), 1207-1219.

15. Susmel, L., Tovo, R., Lazzarin, P. (2005). The mean stress effect on the high-cycle fatigue strength from a multiaxial fatigue point of view. International Journal of Fatigue, 27(8), 928-943.

16. Chaboche, J. L. (1992). Damage induced anisotropy: On the difficulties associated with the active/passive unilateral condition. International Journal of Damage Mechanics, 1(2), 148-171.

17. Altenbach, H., Zolochevsky, A. A. (1994). Eine energetische Variante der Theorie des Kriechens und der Langzeitfestigkeit für isotrope Werkstoffe mit komplizierten Eigenschaften. Zeitschrift für Angewandte Mathematik und Mechanik, 74(3), 189-199. (in German)

18. Wood, J. L. (1971). Dynamic response of human cranial bone. Journal of Biomechanics, 4(1), 1-12.

19. Atsumi, N., Tanaka, E., Iwamoto, M., Hirabayashi, S. (2017). Constitutive modeling of cortical bone considering anisotropic inelasticity and damage evolution. Bulletin of the JSME. Mechanical Engineering Journal, 4(4), 17-00095-1-17-00095-18.

20. McElhaney, J. H. (1966). Dynamic response of bone and muscle tissue. Journal of Applied Physiology, 21(4), 1231-1236.

21. Yamada, H. (1970). Strength of Biological Materials. Baltimore: Williams \& Wilkins Company, 296 p.

22. Garcia, D. (2006). Elastic Plastic Damage Laws for Cortical Bone. Ph.D Thesis, Lausanne: Swiss Federal Institute of Technology, $197 \mathrm{p}$.

23. Mirzaali, M. J., Bürki, A., Schwiedrzik, J., Zysset, P. K., Wolfram, U. (2015). Continuum damage interactions between tension and compression in osteonal bone. Journal of the Mechanical Behavior of Biomedical Materials, 49, 355-369.

24. Li, S., Demirci, E., Silberschmidt, V. V. (2013). Variability and anisotropy of mechanical behavior of cortical bone in tension and compression. Journal of the Mechanical Behavior of Biomedical Materials, 21, 109-120.

25. Thiagarajan, G., Begonia, M. T., Dallas, M., Lara-Castillo, N., Scott, J. M., Johnson, M. L. (2018). Determination of elastic modulus in mouse bones using a nondestructive micro-indentation technique using reference point indentation. Journal of Biomechanical Engineering, 140(7), 071011-1 - 071011-11.

26. Abdel-Wahab, A. A., Alam, K., Silberschmidt, V. V. (2011). Analysis of anisotropic viscoelastoplastic properties of cortical bone tissues. Journal of the Mechanical Behavior of Biomedical Materials, 4(5), 807-820.

27. Nyman, J. S., Leng, H., Dong, X. N., Wang, X. (2009). Differences in the mechanical behavior of cortical bone between compression and tension when subjected to progressive loading. Journal of the Mechanical Behavior of Biomedical Materials, 2(6), 613-619.

28. Dong, X. N., Acuna, R. L., Luo, Q., Wang, X. (2012). Orientation dependence of progressive post-yield behavior of human cortical bone in compression. Journal of Biomechanics, 45(16), 2829-2834.

29. Dong, X. N., Luo, Q., Wang, X. (2013). Progressive post-yield behavior of human cortical bone in shear. Bone, 53(1), 1-5.

30. Nyman, J. S., Roy, A., Reyes, M. J., Wang, X. (2009). Mechanical behavior of human cortical bone in cycles of advancing tensile strain for two age groups. Journal of Biomedical Materials Research Part A, 89(2), 521-529.

31. Dendorfer, S., Maier, H. J., Taylor, D., Hammer, J. (2008). Anisotropy of the fatigue behaviour of cancellous bone. Journal of Biomechanics, 41(3), 636-641.

32. Nikitenko, A. F., Sosnin, O. V., Torshenov, N. G., Shokalo, I. K. (1971). Creep of hardening materials with different properties in tension and compression. Journal of Applied Mechanics and Technical Physics, 12(2), 277-281.

33. Nikitenko, A. F., Sosnin, O. V., Torshenov, N. G., Shokalo, I. K. (1976). Strength characteristics of titanium alloys. Journal of Applied Mechanics and Technical Physics, 17(6), 849-852.

34. Nikitenko, A. F., Sosnin, O. V. (1976). Creep and long-term strength under cyclic loading conditions. Strength of Materials, 8(12), 1395-1398.

35. Konstantinidis, L., Helwig, P., Hirschmüller, A., Langenmair, E., Südkamp, N. P., Augat, P. (2016). When is the stability of a fracture fixation limited by osteoporotic bone? Injury, 47(S2), S27-S32.

36. Zolochevsky, A., Galishin, A., Sklepus, S., Parkhomenko, L., Gnitko, V., Kühhorn, A., Leyens, C. (2013). Benchmark creep tests for thermal barrier coatings. Journal of the National Technical University «Kharkiv Polytechnic Institute». Series «Machine-building and CAD», (23), 158-178.

37. Zolochevskii, A. A. (1982). Allowance for differences in strain resistance in the creep of isotropic and anisotropic materials. Journal of Applied Mechanics and Technical Physics, 23(4), 591-596.

38. Zolochevskii, A. A. (1985). Tensor relationship in the theories of elasticity and plasticity of anisotropic composite materials with different tensile and compressive strength. Mechanics of Composite Materials, 21(1), 41-46.

39. Kim, J. H., Lee, M. G., Chung, K., Youn, J. R., Kang, T. J. (2006). Anisotropic-asymmetric yield criterion and anisotropic hardening law for composite materials: Theory and formulations. Fibers and Polymers, 7(1), 42-50.

40. Wang, J., Xiao, Y. (2017). Some improvements on Sun-Chen's one-parameter plasticity model for fibrous 
composites. Part I: Constitutive modelling for tension-compression asymmetry response. Journal of Composite Materials, 51(3), 405-418.

41. Wang, J., Xiao, Y., Inoue, K., Kawai, M., Xue, Y. (2019). Modeling of nonlinear response in loadingunloading tests for fibrous composites under tension and compression. Composite Structures, 207, 894908.

42. Pasynok, M. A. (2000). Development of Anisotropic Creep Analysis Methods Taking into Account Damage of Flat Structural Elements of Machines. Ph.D Thesis, Kharkiv: National Technical University «Kharkiv Polytechnic Institute», 193p. (in Ukrainian)

43. Zolochevsky, A. A. (1991). Creep of isotropic and anisotropic materials with different behaviour in tension and compression. In Zyczkowski M. (ed.), Creep in Structures (pp. 217-220). Berlin: Springer.

44. Zolochevsky, A. (1995). The formulation of constitutive equations for anisotropic materials with different behaviour in tension and compression. In Parker D. F. and England A. H. (eds.), IUTAM Symposium on Anisotropy, Inhomogeneity and Nonlinearity in Solid Mechanics (pp. 351-356). Dordrecht: Springer.

45. Voyiadjis, G. Z., Zolochevsky, A. (1998). Creep theory for transversely isotropic solids sustaining unilateral damage. Mechanics Research Communications, 25(3), 299-304.

46. Voyiadjis, G. Z., Thiagarajan, G. (1995). An anisotropic yield surface model for directionally reinforced metal-matrix composites. International Journal of Plasticity, 11(8), 867-894.

47. Voyiadjis, G. Z., Zolochevsky, A. (1998). Modeling of secondary creep behavior for anisotropic materials with different properties in tension and compression. International Journal of Plasticity, 14(10-11), 10591083.

48. Baca, V., Horak, Z. (2007). Letter to the Editor: Comparison of isotropic and orthotropic material property assignments on femoral finite element models under two loading conditions. Medical Engineering and Physics, 29(8), 935.

49. Pirohov, Y. N., Tiazhelov, O.A. (2014). The role of bone remodeling process in the development of the femoral head necrosis in injuries and diseases: Conception of pathogenesis (Review of literature). The Journal of Orthopaedics, Traumatology and Prosthetics, (4), 64-72.

50. Hambli, R. (2014). Connecting mechanics and bone cell activities in the bone remodeling process: An integrated finite element modeling. Frontiers in Bioengineering and Biotechnology, 2(6), 1-12.

51. Hambli R., Almitani, K. H., Chamekh, A., Toumi, H., Tavares, J. M. R. (2015). A theory for bone resorption based on the local rupture of osteocytes cells connections: A finite element study. Mathematical Biosciences, 262, 46-55.

52. Schmitt, M., Allena, R., Schouman, T., Frasca, S., Collombet, J. M., Holy, X., Rouch, P. (2016). Diffusion model to describe osteogenesis within a porous titanium scaffold. Computer Methods in Biomechanics and Biomedical Engineering, 19(2), 171-179.

53. Roshan-Ghias, A., Vogel, A., Rakotomanana, L., Pioletti, D. P. (2011). Prediction of spatio-temporal bone formation in scaffold by diffusion equation. Biomaterials, 32(29), 7006-7012.

54. Roshan-Ghias, A., Terrier, A., Jolles, B. M., Pioletti, D. P. (2014). Translation of biomechanical concepts in bone tissue engineering: from animal study to revision knee arthroplasty. Computer Methods in Biomechanics and Biomedical Engineering, 17(8), 845-852.

55.Zolochevsky, A., Grabovskiy, A. V., Parkhomenko, L., Lin, Y. S. (2012). Coupling effects of oxygen surface exchange kinetics and membrane thickness on chemically induced stresses in perovskite-type membranes. Solid State Ionics, 212, 55-65.

56.Zolochevsky, A., Parkhomenko, L., Kühhorn, A. (2012). Analysis of oxygen exchange-limited transport and chemical stresses in perovskite-type hollow fibers. Materials Chemistry and Physics, 135(2-3), 594603.

57. Zolochevsky, A., Grabovskiy A.V., Parkhomenko L., Lin Y.S. (2013). Transient analysis of oxygen nonstoichiometry and chemically induced stresses in perovskite-type ceramic membranes for oxygen separation. Journal of the National Technical University «Kharkiv Polytechnic Institute». Series «Machine-building and CAD », (1), 179-189.

58. Fletcher, J. W., Windolf, M., Richards, R. G., Gueorguiev, B., Buschbaum, J., Varga, P. (2019). Importance of locking plate positioning in proximal humeral fractures as predicted by computer simulations. Journal of Orthopaedic Research, https://doi.org/10.1002/jor.24235.

59. Madeo, A., George, D., Lekszycki, T., Nierenberger, M., Rémond, Y. (2012). A second gradient continuum model accounting for some effects of micro-structure on reconstructed bone remodelling. Comptes Rendus Mécanique, 340(8), 575-589.

60. Scala, I., Spingarn, C., Rémond, Y., Madeo, A., George, D. (2017). Mechanically-driven bone remodeling simulation: Application to LIPUS treated rat calvarial defects. Mathematics and Mechanics of Solids, 22(10), 1976-1988.

61.Lotz, J. C., Gerhart, T. N., Hayes, W. C. (1991). Mechanical properties of metaphyseal bone in the proximal femur. Journal of Biomechanics, 24(5), 317-329. 
62.Zolochevsky, A. A., Damasevich, S. V. (1990). Method for analysis of nonlinear elastic deformation of shells from materials with tension/compression asymmetry. Papers of Universities. Series «Mechanical Engineering», (5), pp. 30-34.

63.Zolochevsky, A., Galishin, A., Sklepus, S., Voyiadjis, G. Z. (2007). Analysis of creep deformation and creep damage in thin-walled branched shells from materials with different behavior in tension and compression. International Journal of Solids and Structures, 44(16), 5075-5100.

64.Zolochevsky, A., Galishin, A., Kühhorn, A., Springmann, M. (2009). Transversal shear effect in moderately thick shells from materials with characteristics dependent on the kind of stress state under creep-damage conditions: Theoretical framework. Technische Mechanik, 29(1), 38-47.

65. Galishin, A., Zolochevsky, A., Kühhorn, A., Springmann, M. (2009). Transversal shear effect in moderately thick shells from materials with characteristics dependent on the kind of stress state under creep-damage conditions: Numerical modeling. Technische Mechanik, 29(1), 48-59.

66. Cowin, S. C. (1987). Bone remodeling of diaphyseal surfaces by torsional loads: theoretical predictions. Journal of Biomechanics, 20(11-12), 1111-1120.

67. Zioupos, P., Currey, J. D., Mirza, M. S., Barton, D. C. (1995). Experimentally determined microcracking around a circular hole in a flat plate of bone: comparison with predicted stresses. Philosophical Transactions of the Royal Society of London. Series B «Biological Sciences», 347(1322), 383-396.

68. Zolochevsky, A., Sklepus, S., Hyde, T. H., Becker, A. A., Peravali, S. (2009). Numerical modeling of creep and creep damage in thin plates of arbitrary shape from materials with different behavior in tension and compression under plane stress conditions. International Journal for Numerical Methods in Engineering, 80(11), 1406-1436.

69. Güzelsu, N., Saha, S. (1981). Electro-mechanical wave propagation in long bones. Journal of Biomechanics, 14(1), 19-33.

70. Misra, J. C., Murty, V. V. T. N. (1981). Stress concentration around cracks in long bones. Forschung im Ingenieurwesen, 47(2), 37-0.

71. Guo, X. D., Cowin, S. C. (1992). Periosteal and endosteal control of bone remodeling under torsional loading. Journal of Biomechanics, 25(6), 645-650.

72. Zolochevsky, A., Sklepus, S., Galishin, A., Kühhorn, A., Kober, M. (2014). A comparison between the 3D and the Kirchhoff-Love solutions for cylinders under creep-damage conditions. Technische Mechanik, 34(2), 104-113.

73. Galishin, A. Z., Zolochevsky, A. A., Sklepus, S. M. (2018). Study of creep and damage for a hollow cylinder on the basis of space and refined shell models. Journal of Mathematical Sciences, 231(5), 629640 .

74. Malanchuk, V. A., Shydlovsky, M. S., Kopchak, A. V. (2010). The experimental study of the process of stress relaxation in mandibular bone. The Journal of Stomatology, (2), 90-96.

75. Zolochevsky, A., Martynenko, A., Kühhorn, A. (2012). Structural benchmark creep and creep damage testing for finite element analysis with material tension-compression asymmetry and symmetry. Computers and Structures, 100-101, 27-38.

76. Shydlovsky, M. S., Laksha, A. M., Burianov O. A. (2008). Design of deformation characteristics of system fixation used in treatment of damaged bone and hip joint. Journal of the National Technical University of Ukraine «Kyiv Polytechnic Institute». Series «Machine-building», (54), 51-62. (in Russian)

\section{БІОМЕХАНІЧНИЙ АНАЛІЗ РІЗНООПІРНОСТІ РОЗТЯГУ-СТИСКУ, АНІЗОТРОПІЇ ТА НЕОДНОРІДНОСТІ РЕКОНСТРУКЦІЇ КІСТКИ В ЗВ'ЯЗКУ З ЛІКУВАННЯМ ПЕРИПРОТЕЗНИХ ПЕРЕЛОМІВ}

Золочевський О. О., Мартиненко О. В.

Введення. Відновлення кістки після періпротезного перелому є критичною проблемою в ортопедії.

Мета. Таким чином, дослідження щодо пошуку нових медичних рішень $\epsilon$ необхідними, особливо в контексті старіння населення України. Важливість біомеханіки, яка пов\&\#39;язана із застосуванням принципів, концепцій $і$ методів механіки твердого тіла і рідини до тіла людини в русі і в спокої, давно визнана в якості основи для подальших експериментальних і теоретичних досліджень щодо тканин скелета.

Матеріали та методи. Різні аспекти біомеханіки вимагають використання різних концепцій і методів механіки твердого тіла і рідини. Ремоделювання відбувається протягом усього життя кістки, тому цей процес можна розглядати як основний детермінант механічних властивостей кістки і імпланту. Біомеханічний аналіз, наведений у цьому огляді, стосується розуміння того, як механічні сигнали і молекулярні механізми впливають на лікування періпротезних переломів стегнової кістки після ендопротезування кульшового суглоба, типу В1 i C відповідно до Ванкуверської класифікації, за допомогою пластини з менш інвазивною системою стабілізації (LISS) і гвинтів-фіксаторів.

Результати. Ідентифікація таких параметрів як механічні властивості кістки, титанових сплавів (протез тазостегнового суглоба, покриття, LISS-пластини, гвинти) і інтерфейсу імплантат / біоматеріал / кістка при механічному і біохімічному навантаженні, які дуже важливі для прогнозування результатів артропластики, були експериментально досліджені з урахуванням упругопластичної деформації, повзучості, втоми, а також розвитку 
пошкоджень в наведених матеріалах. Серед основних особливостей деформації були досліджені асиметрія розтягування-стиснення, анізотропія i неоднорідність механічних властивостей. Ми використовували трьохвимірну модель кінцевих елементів, отриману в результаті реконструкції магнітно-резонансних (томографічних) зображень і зображень протягом лікування.

Висновки. В результаті аналізу цієї моделі було встановлено, що темпи лікування періпротезних переломів стегнової кістки після тотального ендопротезування кульшового суглоба з використанням пластин LISS і гвинтів для внутрішньої фіксації можна контролювати за допомогою пакета програм ABAQUS (або ANSYS) для відтворення характерних особливостей кістки і імпланту при реконструкції кісток з метою підвищення швидкості загоєння перелому і скорочення тривалості лікування.

КЛЮЧОВІ СЛОВА: перипротезний перелом, LISS-пластина, біомеханіка, анізотропія, неоднорідність, різноопірність розтягу-стиску

\section{ІНФОРМАЦІЯ ПРО АВТОРІВ}

Золочевський Олександр, д.т.н., доц., завідувач лабораторії науково-виробничого центру «Політех», вул. О. Яроша, 14, Харків, Україна, 61145, e-mail: zolochevsky55@ukr.net,

https://orcid.org/0000-0001-6632-4292

Мартиненко Олександр, д.физ-мат.н., професор кафедри гігієни та соціальної медицини Харківського національного університету імені В. Н. Каразіна, пл. Свободи, 6, Харків, Україна, 61022 , e-mail: Alexander.v.martynenko@karazin.ua, https://orcid.org/0000-0002-0609-2220

\section{БИОМЕХАНИЧЕСКИЙ АНАЛИЗ РАЗНОСОПРОТИВЛЯЕМОСТИ РАСТЯЖЕНИЮ- СЖАТИЮ, АНИЗОТРОПИИ И НЕОДНОРОДНОСТИ РЕКОНСТРУКЦИИ КОСТИ В СВЯЗИ С ЛЕЧЕНИЕМ ПЕРИПРОТЕЗНИХ}

\section{Золочевский А. А., Мартыненко А. В.}

Введение. Восстановление кости после перипротезного перелома является критической проблемой в ортопедии.

Цель. Таким образом, исследования для предоставления новых медицинских решений являются необходимыми, особенно в контексте старения населения Украины. Важность биомеханики, которая связана с применением принципов, концепций и методов механики твердого тела и жидкости к телу человека в движении и в покое, давно признана в качестве основы для дальнейших экспериментальных и теоретических исследований касательно тканей скелета.

Материалы и методы. Различные аспекты биомеханики требуют использования различных концепций и методов механики твердого тела и жидкости. Ремоделирование происходит в течение всей жизни кости, поэтому этот процесс можно рассматривать как основной детерминант механических свойств кости и имплантата. Биомеханический анализ, приведенный в настоящем обзоре, касается понимания того, как механические сигналы и молекулярные механизмы влияют на лечение перипротезних переломов бедренной кости после эндопротезирования тазобедренного сустава, типа В1 и С согласно Ванкуверской классификации, с помощью пластины с менее инвазивной системой стабилизации (LISS) и винтов-фиксаторов.

Результаты. Идентификация таких параметров как механические свойства кости, титановых сплавов (протез тазобедренного сустава, покрытие, LISS-пластины, винты) и интерфейса имплантат/биоматериал/ кость при механическом и биохимическом нагружении, которые очень важны для прогнозирования результатов артропластики, были экспериментально исследованы с учетом упругопластической деформации, ползучести, усталости, а также развитие повреждений в обсуждаемых материалах. Среди основных особенностей деформации были исследованы асимметрия растяжения-сжатия, анизотропия и неоднородность механических свойств. Мы использовали трехмерную модель конечных элементов, полученную в результате реконструкции магнитнорезонансных (томографических) изображений и изображений в ходе лечения.

Выводы. В результате анализа этой модели было установлено, что темпы лечения перипротезных переломов бедренной кости после тотального эндопротезирования тазобедренного сустава с использованием пластин LISS и винтов для внутренней фиксации можно контролировать с помощью пакета программ ABAQUS (или ANSYS) для воспроизведения характерных особенностей кости и имплантата при реконструкции костей с целью повышения скорости заживления перелома и сокращения продолжительности лечения.

КЛЮЧЕВЫЕ СЛОВА: перипротезний перелом, LISS-пластина, биомеханика, анизотропия, неоднородность, разносопротивляемость растяжению-сжатию

\section{ИНФОРМАЦИЯ ОБ АВТОРАХ}

Золочевский Александр, д.т.н., доц., заведующий лаборатории научно-производственного центра «Політех», ул. О. Яроша, 14, Харьков, Украина, 61145, e-mail: zolochevsky55@ukr.net,

https://orcid.org/0000-0001-6632-4292

Мартиненко Александр, д.физ-мат.н., профессор кафедры гигиены и социальной медицины Харьковского національного университета имени В. Н. Каразіна, пл. Свободи, 6, Харків, Україна, 61022, e-mail: Alexander.v.martynenko@karazin.ua, https://orcid.org/0000-0002-0609-2220 